\title{
37. DATA REPORT: POST-CRUISE CORRECTION OF CORE DEPTHS OF MADEIRA ABYSSAL PLAIN SITES FOR GENERAL REFERENCE USE ${ }^{1}$
}

\author{
S.M. Lebreiro ${ }^{2}$ and P.P.E. Weaver ${ }^{2}$
}

\begin{abstract}
Post-cruise corrections have been introduced in the core depths initially registered aboard ship to eliminate voids/gaps and intervals of disturbed material. These corrections have generally led to a shortening of the length of recovered sediment in each core and have eliminated all instances of recovered core being longer than the drilled interval. The adjustments have been done for the three Madeira Abyssal Plain sites (Holes 950A, 951A, 951B, and 952A). Easily used tables for correcting depths of samples taken in the future from any core from Holes 950A, 951A, 951B, and 952A are included on the CD-ROM accompanying this volume.
\end{abstract}

\section{NEED FOR CORRECTION}

The Ocean Drilling Program standard drilling equipment cores a maximum of $9.7 \mathrm{~m}$ of material per core. Standard practice to date has regarded the total core recovery to include all cored sediment, regardless of quality, together with any voids that are present within the split core. This often leads to the recovered length being longer than the drilled length. Although this situation could arise through core expansion, (e.g., because of gas within the core), we believe the elimination of obvious sections of drilling disturbance and voids where the core has split apart will give a more realistic representation of the recovered lengths.

\section{METHOD}

In this paper we have regarded the driller's estimation of the depth of the top of each core to be accurate, and we have only adjusted the length of recovered sediment in each core relative to this core-top depth. These core-top depths are listed in the coring summary tables (Schmincke, Weaver, Firth, et al., 1995; pp. 56, 109, and 139). We have, however, taken the measured length of each section from the visual core description sheets produced by the sedimentologists on board and not from the coring summary tables. Sections are frequently 1 to $2 \mathrm{~cm}$ shorter than their listed length, and core catchers often have quite different lengths. Individual corrections made per core consist of the following:

1. Subtraction of voids where they are clearly caused by sediment splitting apart (e.g., during core handling on deck or during splitting). Any voids related to sediment fallout should not be eliminated. In practice, sediment fallout is rare and was not encountered in the three sites discussed here.

2. Removal of slumped and disturbed sediment at the top of each core. This material is probably produced by the advance of the main drill bit and lies on top of the true sediment surface before hydraulic piston coring commences. It appears as thoroughly disturbed sediment at the top of the core.
3. Paleosamples taken at the core catcher are considered to have a constant length of $3 \mathrm{~cm}$; thus, $3 \mathrm{~cm}$ was added to the total core length described on board.

If, after the above corrections, core length still exceeded drilled length (i.e., $>100 \%$ recovery), the length of each section was adjusted using the following equation:

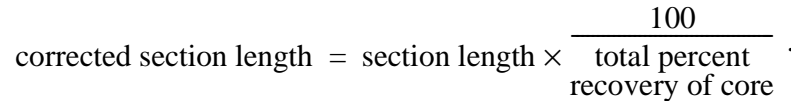

These corrections have provided much more accurate methods of assessing the true recovery, which is very important when trying to estimate the number of sedimentary units per drilled interval.

\section{Tables for General Reference}

The three coring summary tables printed in Schmincke, Weaver, Firth et al, (1995) concerning the Madeira Abyssal Plain (MAP) sites are corrected and presented here (Tables 1-3 on CD-ROM, back pocket, this volume). These tables have served for calculating corrected sample depths for scientists working in the MAP sites (papers in this volume) and are aimed for use in any samples taken in the future from Holes 950A, 951A, 951B, and 952A. A file of simple use is included in the CD-ROM accompanying this volume.

\section{ACKNOWLEDGMENTS}

This work was supported by the European Commission on Marine Science and Technology (MAST II) program (Sediment Transport on European Atlantic Margins [STEAM]) grant MAS2-CT94-0083), and Natural Environment Research Council (NERC) grant no. GST/ 02/990.

\section{REFERENCES}

Schmincke, H.-U., Weaver, P.P.E., Firth, J.V., et al., 1995. Proc. ODP, Init. Repts., 157: College Station, TX (Ocean Drilling Program).
${ }^{1}$ Weaver, P.P.E., Schmincke, H.-U., Firth, J.V., and Duffield, W. (Eds.), 1998. Proc. ODP, Sci. Results, 157: College Station, TX (Ocean Drilling Program).

${ }^{2}$ Southampton Oceanography Centre, Empress Dock, Southampton SO14 3ZH, United Kingdom. ppew@soc.soton.ac.uk (Present address: CSIC-Instituto de Ciencias del Mar, Dept. de Geologica Marina y Oceanografia Fisica, Paseo Juan de Borbon, s/n 08039, Barcelona, Spain. lebreiro@icm.csic.es).
Date of initial receipt: 7 August 1996

Date of acceptance: 8 March 1997

Ms 157SR-148

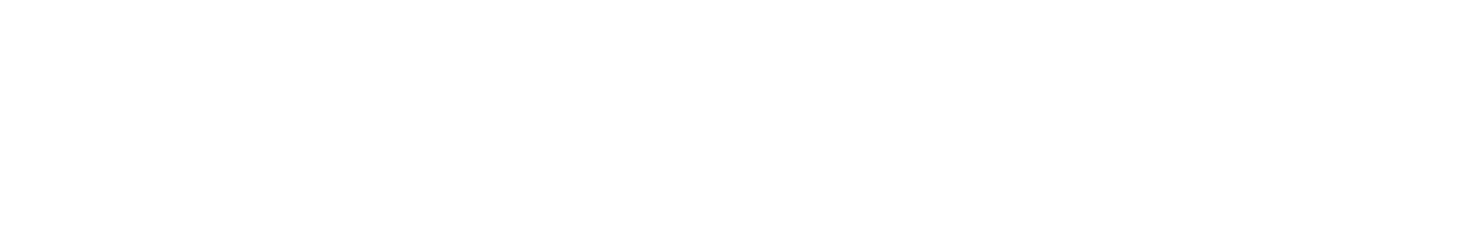

